\title{
Association between responses obtained using adaptability and stability methods in alfalfa
}

\section{Associação entre respostas obtidas por meio de métodos de adaptabilidade e estabilidade em alfafa}

\section{Moysés Nascimento ${ }^{1 *}$; Ana Carolina Campana Nascimento ${ }^{1}$; Marcelo Ângelo Cirillo²; Adésio Ferreira ${ }^{3}$; Luiz Alexandre Peternelli ${ }^{1}$; Reinaldo Ferreira de Paula ${ }^{4}$}

\begin{abstract}
This study aimed to evaluate the association between responses obtained using methods of adaptability and stability by using correspondence analysis. The forage yield of 92 genotypes of alfalfa (Medicago sativa L.) was investigated. The trial had a randomized block design, with 2 replicates, and the data were used to test the reliability of the different methods. Twenty cuttings were obtained from each genotype between November 2004 and June 2006. Each cutting was grown in a different environment. The estimates of adaptability and stability were obtained using the methods of Eberhart and Russell (1966), Cruz, Torres and Vencovsky (1989), Nascimento et al. (2009b), and Lin and Binns (1988). Following the association analysis, correspondence analysis was conducted for determining association and discriminating the responses obtained using the methods of adaptability and stability. The unfavorable (D) and unpredictable unfavorable (DI) responses obtained using the methods of Lin and Binns (1988) and Eberhart and Russell (1966), respectively, were discrepant in relation to other responses obtained using these methods. The greatest association between responses was confirmed using the methods of Eberhart and Russell (1966) and Cruz, Torres and Vencovsky (1989).
\end{abstract}

Key words: Correspondence analysis, genotype $\times$ environment interaction, multiple centroid method, Eberhart and Russell (1966), Cruz, Torres, and Vencovsky (1989)

\section{Resumo}

Este trabalho teve por objetivo avaliar a associação entre as respostas de alguns métodos de adaptabilidade e estabilidade por meio da técnica multivariada: análise de correspondência. Foram utilizados dados provenientes de um experimento sobre produção de matéria seca de 92 genótipos de alfafa (Medicago sativa) realizado em blocos ao acaso, com duas repetições. Os genótipos foram submetidos a 20 cortes, no período de novembro de 2004 a junho de 2006. Cada corte foi considerado um ambiente. As estimativas de adaptabilidade e de estabilidade de produção foram obtidas pelos métodos de Eberhart e Russell (1966), Cruz, Torres e Vencovsky (1989), método centróide ampliado e Lin e Binns (1988). Após a análise de associação, verificou-se que a técnica de análise de correspondência mostrou-se eficaz para o estudo da associação e capacidade de discriminação das respostas dos métodos de adaptabilidade e estabilidade. As respostas desfavorável (D) e desfavorável imprevisível (DI) associadas aos métodos de Lin e Binns (1988) e Eberhart e Russell (1966), respectivamente, são discrepantes em relação às

\footnotetext{
${ }^{1}$ Profs. do Dept ${ }^{\circ}$ de Estatística, Universidade Federal de Viçosa, UFV, Viçosa, MG. E-mail: moysesnascim@ufv.br; ana.campana@ ufv.br; peternelli@ufv.br

${ }^{2}$ Prof. do Dept ${ }^{\circ}$ de Ciências Exatas, Universidade Federal de Lavras, UFLA, Lavras, MG. E-mail: cirillo@ufla.br

${ }_{3}^{3}$ Prof. do Centro Agropecuário, Universidade Federal do Espírito Santo,UFES, Alegre, ES. E-mail: adesio@gmail.com

${ }^{4}$ Pesquisador da Embrapa Pecuária Sudeste, São Carlos, SP. E-mail: reinaldo.ferreira@embrapa.br

* Author for correspondence
} 
outras respostas obtidas por estes métodos. Dentre todos os métodos avaliados os que possuem maior associação entre as respostas são os métodos de Eberhart e Russell (1966) e Cruz et al. (1989).

Palavras-chave: Análise de correspondência, interação genótipos x ambientes, método dos centroides múltiplos, Eberhart e Russell (1966), Cruz, Torres e Vencovsky (1989)

\section{Introduction}

An understanding of genotype $\times$ environment (GE) interaction components is essential for genetic improvement. However, there is lack of detailed information on the performance of each cultivar under varying environmental conditions (CRUZ; REGAZZI; CARNEIRO, 2004). Therefore, analysis of adaptability and stability of cultivars is extremely important and necessary, since these factors help in identifying and recommending better species in different environments.

Several methodologies for analyzing adaptability and stability have been described in the literature. The methods of Eberhart and Russell (1966); Cruz, Torres and Vencovsky (1989); and Nascimento et al. (2011) involve the use of regression analysis as a statistical principle. On the other hand, there are non-parametric methods, such as those developed by Lin and Binns (1988), non-parametric regression (NASCIMENTO et al., 2010), centroid method (ROCHA et al., 2005) and its subsequently modified method, as well as multiple and extended centroid (NASCIMENTO et al., 2009a, 2009b). In addition, there is a AMMI - additive multiplicative models interaction model (GAUCH JUNIOR, 2006).

Because of the numerous adaptability and stability methodologies and the relevance of these techniques for the success of a cultivar improvement program, a comparison among these methods is of extreme importance and has promoted great interest among investigators. For example, Rosse, Vencovsky, and Ferreira (2002) compared linear and non-linear regression methods to evaluate phenotypic stability in sugarcane plants. Sabaghnia, Dehghani, and Sabaghpour (2006) compared 10 non-parametric methods for evaluating stability of 11 lentil genotypes. Silva and Duarte (2006) evaluated several statistical methods of GE interaction analysis and emphasized adaptability and phenotypic stability in 28 soybean genotypes. Mahammadi and Amri (2008) used 20 parametric and non-parametric methods to compare the selection of Triticum durum genotypes.

In general, methodologies are compared by calculating the Spearman's correlation coefficient between parameter estimates obtained by each method. However, due to the qualitative nature of the responses, since most methods involve the conversion of numerical values related to adaptability and stability parameters into classes of response, the multivariate technique of correspondence analysis becomes more suitable for the analysis of the association between responses obtained using these methods.

The correspondence analysis is a descriptive/ exploratory technique of multivariate analysis, which allows multidimensional graphical representation of the dependence between lines and/or columns of a contingency table of 2 entries, where lines and columns represent types of categorical variables. As an example of this methodology, Lopes Junior et al. (2012) characterized 18 dairy production systems for zootechnical management, production, and milk quality results by using multivariate statistical techniques such as correspondence and grouping analyses. Carmo and Assis (2012) used this technique to verify possible relations between chemical properties, soil texture, and arboreal and bushy species distribution in the State Park of Guartelá (PR, Brazil).

This study aimed to determine the association between responses obtained using adaptability and stability methods by using the multivariate technique of correspondence analysis, considering 
that responses obtained using these methods may be considered as levels of a qualitative variable.

\section{Material and Methods}

Data on the production of dry matter from 92 alfalfa genotypes with 20 cuttings each were analyzed. The experiment was delineated on the basis of randomized blocks, with 2 replications. The plots constituted of five 5-m rows. One row on each side and $0.50 \mathrm{~m}$ on each plot end was considered border. The experiment was conducted by Embrapa Pecuária Sudeste, for the development of alfalfa genotypes that could adapt to different Brazilian ecosystems. The cuttings represented different environmental conditions, since they were planted at different growing seasons from November 2004 to June 2006.
An individual analysis of variance was initially performed in random blocks per cutting on the basis of plot means in order to evaluate the existence of genetic variability between treatments and the relative accuracy of each experiment. Subsequently, multiple analyses of variance were carried out.

When the presence of GE interaction was significantly identified, the behavior of each cultivar was thoroughly evaluated under varying environmental conditions by using the methodologies of Eberhart and Russell (1966); Cruz, Torres and Vencovsky (1989); Nascimento et al. (2009b; multiple centroid method); and Lin and Binns (1988).

The responses obtained using adaptability and stability methodologies evaluated in this study were classified as shown in Table 1. From these results, association analyses were performed between methodologies.

Table 1. Response classes for methodologies of Eberhart and Russell (1966); Cruz, Towers and Vencovsky (1989); Nascimento et al. (2009b), multiple centroid method); and Lin and Binns (1988).

\begin{tabular}{ccc}
\hline Methodology & & Legends \\
\hline \multirow{2}{*}{ Eberhart and Russell (1966) } & GP & General predictable \\
& GU & General unpredictable \\
& FP & Favorable predictable \\
& FU & Favorable unpredictable \\
& UP & Unfavorable predictable \\
Cruz, Torres and Vencovsky (1989) & GP & Gnfavorable unpredictable \\
& GU & General unpredictable \\
& FP & Favorable predictable \\
& FU & Favorable unpredictable \\
& UP & Unfavorable predictable \\
& UU & Unfavorable unpredictable \\
& PI & Predictable ideal \\
& UI & Unpredictable ideal \\
\hline & G & General \\
& F & Favorable \\
& U & Unfavorable \\
\hline & MAXG & Maximum General Adaptability \\
& MAXF & Maximum Favorable Adaptability \\
& MAXU & Maximum Unfavorable Adaptability \\
& MIN & Minimum Adaptability \\
& MEDG & Mean General Adaptability \\
& MEDF & Mean Favorable Adaptability \\
& MEDU & Mean Unfavorable Adaptability \\
\hline
\end{tabular}

Source: Elaboration of the authors. 
The association between responses obtained using the adaptability and stability methodologies was confirmed using the multivariate technique of correspondence analysis. For principal components, correspondence analysis is needed to reduce the dimensionality of a matrix and visualize similarities in a lower dimension subspace, usually 2 or 3.

Considering the contingency table in brief (Table 2), the correspondence analysis can be described as follows:

Table 2. Contingency table of 2 categorical variables with $p$ and $q$ classes.

\begin{tabular}{|c|c|c|c|c|c|c|}
\hline & & \multicolumn{4}{|c|}{ Variable Y } & \multirow{2}{*}{ Total } \\
\hline & & 1 & 2 & $\ldots$ & $q$ & \\
\hline \multirow{4}{*}{ Variable X } & 1 & $\mathrm{n}_{11}$ & $\mathrm{n}_{12}$ & $\ldots$ & $\mathrm{n}_{1 \mathrm{q}}$ & $\mathrm{n}_{1}$ \\
\hline & 2 & $\mathrm{n}_{21}$ & $\mathrm{n}_{22}$ & $\ldots$ & $\mathrm{n}_{2 \mathrm{q}}$ & $\mathrm{n}_{2}$ \\
\hline & $\ldots$ & $\ldots$ & $\ldots$ & $\ldots$ & $\ldots$ & $\ldots$ \\
\hline & $p$ & $\mathrm{n}_{\mathrm{p} 1}$ & $\mathrm{n}_{\mathrm{p} 2}$ & $\ldots$ & $\mathrm{n}_{\mathrm{pq}}$ & $\mathrm{n}_{\mathrm{p}}$ \\
\hline \multicolumn{2}{|c|}{ Total } & $\mathrm{n}_{1}$ & $\mathrm{n}_{2}$ & & $\mathrm{n}_{\mathrm{q}}$ & $\mathrm{n}_{-}$ \\
\hline
\end{tabular}

Where nij represents number of elements belonging to category $i$ of variable X (adaptability and stability methods) and to category $j$ of variable Y (another adaptability method).

Source: Elaboration of the authors.

The correspondence matrix, $\mathrm{P}$, associated to the contingency table is formed by entries type $\mathrm{p}_{\mathrm{ij}}=\frac{\mathrm{n}_{\mathrm{ij}}}{\mathrm{n}}$ and vectors denominated profile of lines and columns are, respectively, given as $r^{\prime}=\left(\frac{n_{1}}{n}, \ldots, \frac{n_{p_{n}}}{n}\right)$ and $\mathrm{c}^{\prime}=\left(\frac{\mathrm{n}_{\mathrm{i}}}{\mathrm{n}}, \ldots, \frac{\mathrm{n}_{-\mathrm{q}}}{\mathrm{n}}\right)$.

The variables are graphically represented by matrix decomposition $\widetilde{\mathrm{P}}=\mathrm{P}-\mathrm{rc}$ ' in their eigenvalues and eigenvectors as follows: $\widetilde{\mathrm{P}}=\mathrm{A} \Lambda \mathrm{B}$, in which $\mathrm{A}=\mathrm{D}_{\mathrm{r}}^{1 / 2} \mathrm{U}$ is a dimension matrix $\mathrm{p} \times \mathrm{k}, \mathrm{B}=\mathrm{D}_{\mathrm{c}}^{1 / 2} \mathrm{~V}$ is a dimension matrix $\mathrm{q} \times \mathrm{k}, \mathrm{U}$ and $\mathrm{V}$ are orthogonal matrixes, and $\Lambda$ is the dimension matrix $\mathrm{k} \times \mathrm{k}$ containing eigenvalues of matrix $\widetilde{\mathrm{P}}$ in the increasing order.

After the matrix is decomposed in its singular values, the main coordinates of lines and columns of matrix $\widetilde{P}$ are respectively given as $\mathrm{Y}=\mathrm{D}_{\mathrm{r}}^{-1} \mathrm{~A} \Lambda$ and $\mathrm{Z}=\mathrm{D}_{\mathrm{c}}^{-1} \mathrm{~B} \Lambda$.

Thus, matrix $\widetilde{\mathrm{P}}$ can be expressed as a function of eigenvalues and main coordinates. Hence, $\widetilde{\mathrm{P}}=\sum_{\mathrm{i}=1}^{\mathrm{k}} \hat{\lambda}_{\mathrm{i}} \widetilde{\mathrm{a}}_{\mathrm{i}} \widetilde{\mathrm{b}}_{\mathrm{i}}^{\prime}$, in which $\widetilde{\mathrm{a}}_{\mathrm{i}}$ shows the $\mathrm{i}$-th column of matrix $\mathrm{A} ; \widetilde{\mathrm{b}}_{\mathrm{i}}$ is the $\mathrm{i}$-th column of matrix $\mathrm{B}$.

The total existing variation called inertia is given as $\sum_{i=1}^{k} \lambda_{i}^{2}$, in which $\lambda_{i}$ are eigenvalues of the $\Lambda$ matrix diagonal. The explanation proportion of the main i-th coordinate for total inertia is given as $\frac{\lambda_{i}^{2}}{\sum_{i=1}^{k} \lambda_{i}^{2}}$ (MINGOTI, 2005).

\section{Results and Discussion}

Significant differences were observed between treatments (Table 3), indicating the existence of genetic variability between genotypes for the evaluated trait. The existence of genotypes $\times$ cutting interaction ( $p \leq 0.01)$ was also verified, indicating that the genotypes showed differential performance under different environmental conditions. Therefore, further adaptability and stability analysis studies are needed to evaluate the behavior of cultivars under these environmental variations. 
Table 3. Joint analysis of variance, general average, and coefficients of variation of 20 cuttings of 92 alfalfa genotypes for dry matter production in an experiment carried out from November 2004 to June 2006.

\begin{tabular}{ccc}
\hline Variation sources & GL & Mean squares \\
\hline Blocks & 1 & $2.002 .415,43$ \\
Cultivar (cv) & 91 & $1.384 .475,75^{*}$ \\
Error a & 91 & $574.269,72$ \\
Cutting (Co) & 91 & $62.331 .022,56^{*}$ \\
Error b & 91 & $946.917,67$ \\
$($ Ge $\times$ Co) Interaction & 1.729 & $60.682,46^{* *}$ \\
Error c & 1.729 & $55.851,26$ \\
HP a (\%) & 64.39 & \\
HP b (\%) & 82,69 & \\
HP c (\%) & 20,08 & \\
Means & 1.176 & \\
\hline
\end{tabular}

ns not significant; ${ }^{* *}$ and ${ }^{*}$ significant at $5 \%$ and $1 \%$ probability, respectively, by $\mathrm{F}$ test.

Source: Elaboration of the authors.

Association analysis conducted using the methodologies of Eberhart and Russell (1966) and Cruz, Torres and Vencovsky (1989) showed that the first 2 coordinates explained $91.32 \%$ of total data variability according to inertia. This value, according to principal component studies, is considered sufficient for successful data interpretation (JOHNSON; WICHERN, 1999). In this case, the existence of an association between the responses was verified (Figure 1A).
The responses obtained using the method of Cruz, Torres and Vencovsky (1989) suggested that it was possible to observe the proximity between 2 points represented by responses GU and UI. Existence of heterogeneity was verified when these points were compared with distances of responses FU and UU. Therefore, the methodology of Cruz, Torres and Vencovsky (1989) was found to have adequate discrimination ability for the assessment of adaptability and phenotypic stability of the evaluated genotypes. The same heterogeneity was noted when the responses obtained using the methodology of Eberhart and Russell (1966) were considered.

The responses obtained using the methods of Cruz, Torres and Vencovsky (1989) and Eberhart and Russell (1966) showed that FIC and favorable predictable (FP) values are well represented on the Cartesian plane, revealing an association between them. The same was noted with GU and UI responses, which could also be considered similar, since their coordinates were close. In contrast, regarding responses $\mathrm{GP}$ and $\mathrm{GU}$, since the GP variable profile was relatively superior to the GU variable profile, the centroid of a cloud of points located in Figure 1A tends to be "displaced" toward variable GP. Thus, the similarity between these responses is questionable. 
Figure 1. Correspondence graph for responses of variables obtained using the methodologies of (A) Eberhart and Russell (1966) and Cruz, Torres and Vencovsky (1989); (B) Eberhart and Russell (1966) and Nascimento et al. (2009b, multiple centroid method); (C) Eberhart and Russell (1966) and Lin and Binns (1988); (D) Cruz Torres and Vencovsky (1989) and Nascimento et al. (2009b, multiple centroid method); (E) Cruz Torres and Vencovsky (1989) and Lin and Binns (1988).

(A)

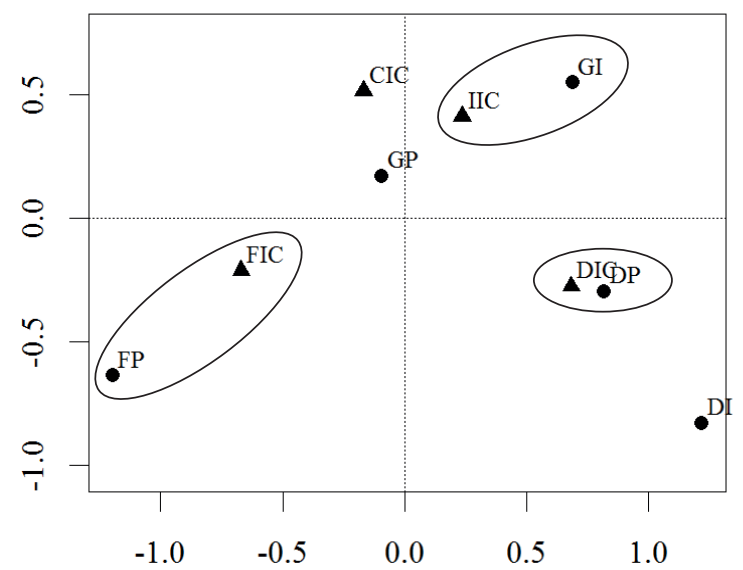

(C)

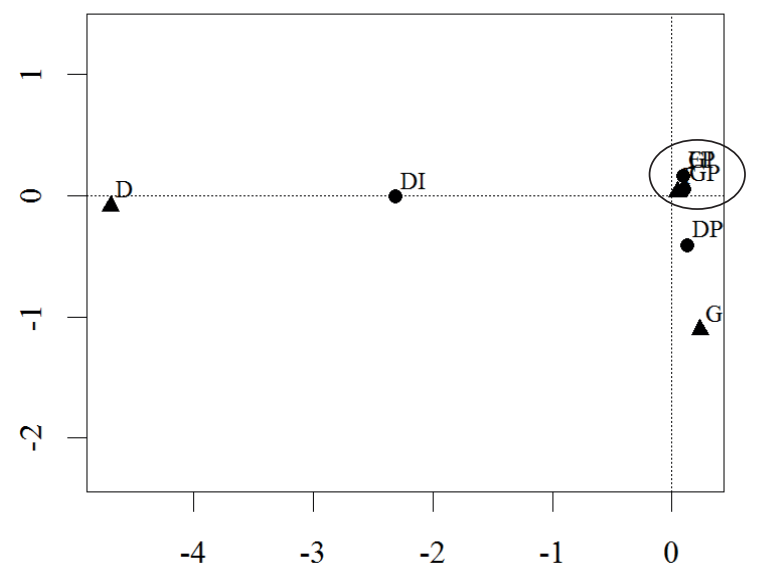

(B)

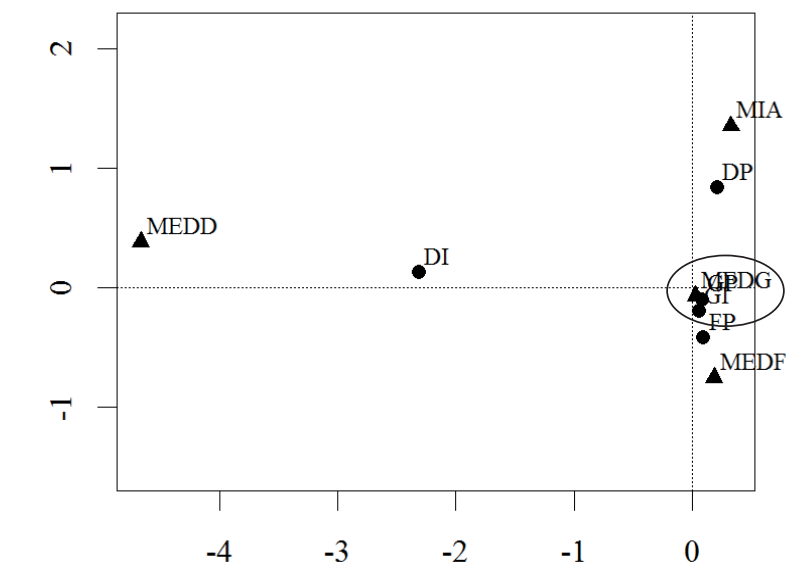

(D)

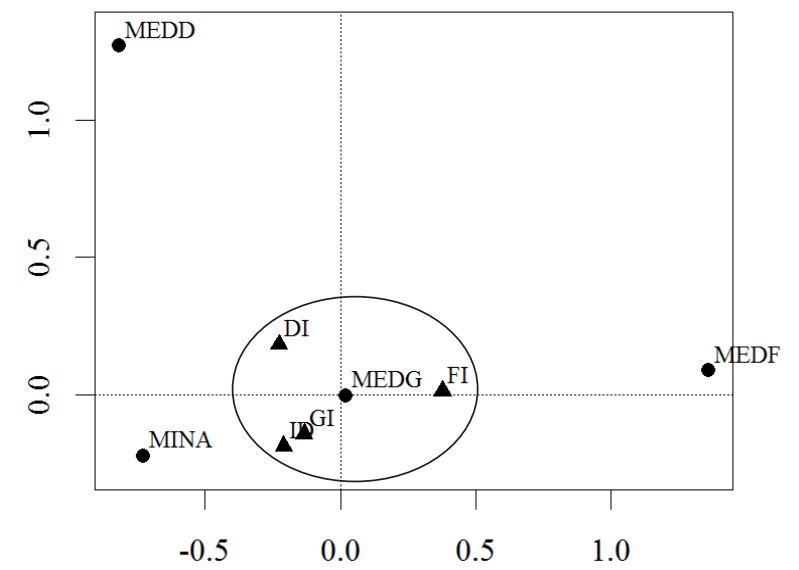

(E)

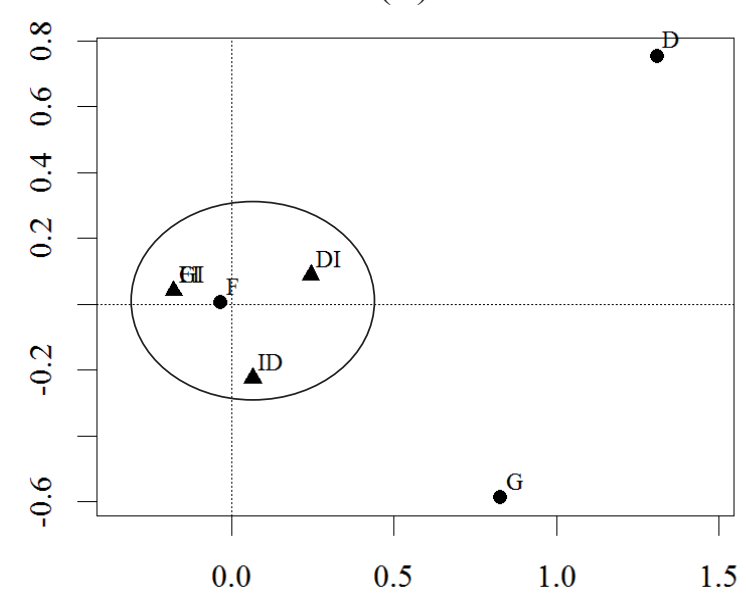

Source: Elaboration of the authors. 
The association analysis between the methodologies of Eberhart and Russell (1966) and Nascimento et al. (2009b) showed that the first 2 coordinates explain $91.7 \%$ of total data variability (Figure 1A). There was remarkable discrimination between responses obtained using these methods. Further, the genotypes were classified in only 3 classes (MEDF, MEDG, and MIN) when evaluated by the multiple centroid method (NASCIMENTO et al., 2009b) and in 5 categories when analyzed by the methodology of Eberhart and Russell (1966).

The analysis of point-by-point association between the responses obtained using these 2 methods was not adequate, due to influence of responses GP, GU, and MEDG in relation to the others, leading to an elevated dispersal of the used components to restore the total variation of variables described in that line and column. Hence, similarity could only reliably be determined for the previously mentioned variables, GP and MEDG (Figure 1B).

The association analysis between the responses obtained using the methods of Eberhart and Russell (1966) and Lin and Binns (1988) suggested that the first 2 components explained $100 \%$ of the total variability of data (Figure 1C).

The responses, unfavorable (U) by Lin and Binns (1988) and unfavorable unpredictable (UU) by Eberhart and Russell (1966), and the other responses showed great heterogeneity. This caused correspondence analysis problems, besides leading to discrepancy between the 2 responses and the others. Thus, the association between the responses obtained using these methods could not be determined.

The correspondence of responses of variables obtained using the methodologies of Cruz, Torres, and Vencovsky (1989) and Nascimento et al. (2009b) presented the first 2 coordinates, explaining $99.31 \%$ of the total data variability (Figure 1D).

All responses obtained using the methodology of Cruz, Torres and Vencovsky (1989) were verified to be within the mean adaptability general category (MEDG) of the extended centroid method (Figure 1D). Besides, the other responses obtained using the multiple centroid method were found to be considerably distant from one another, indicating higher discrimination ability of this methodology. However, if the set of genotypes evaluated showed no remarkable differences, the adaptability analysis conducted using the multiple centroid method was less efficient, since it tended to classify the genotypes evaluated at the MEDG. The same trend was true for the methodologies of Eberhart and Russell (1966) and Lin and Binns (1988).

The correspondence graph for responses of variables obtained using the methodologies of Cruz, Torres and Vencovsky (1989) and Lin and Binns (1988) (Figure 1E) allowed the discrimination of the genotypes. Similar to the association analysis between the responses obtained using the methodology of Eberhart and Russell (1966) and Lin and Binns (1988), there was discrepancy between response $\mathrm{D}$ and other responses obtained using the method of Lin and Binns (1988). In addition, the responses obtained using the Cruz, Torres and Vencovsky (1989) method were closer to the favorable (F) category of those obtained using the Lin and Binns (1988) method.

The association analysis between the methodologies of Lin and Binns (1988) and Nascimento et al. (2009b) was not conducted since non-relevant results were obtained for these methods. In other words, no association was found between the responses obtained using these methods.

The possibility of verifying the discrimination potential (heterogeneity between responses) of each method is essential for determining the correct way of applying these techniques. The use of methods affording great heterogeneity in the evaluation of genotype sets with little difference between responses will lead to genotype classification in one or a few response classes. 
According to the presented discussion, the potentiality of the correspondence analysis technique for studies on the association between responses of adaptability methods in which answers might be turned into categorical variables is noticed. However, in this study, several responses were not associated. This could be because of the lack of genotypes classified in determined categories, or probably the lack of an actual association between them. The lack of association between responses is an interesting finding since, according to the used adaptability method, the conclusions might differ, and therefore might be useful to verify whether the result obtained is in agreement with those obtained by other methods.

In order to obtain better results, further studies are needed on the association analysis between responses obtained using adaptability methods by conducting correspondence analysis of a set of genotypes by using combinations of results obtained for different cultures or by simulating data containing all response classes.

We found an association between FU and IU responses obtained using the methodology of Cruz, Torres and Vencovsky (1989) and FP and FU responses (EBERHART; RUSSELL, 1966). Besides these, only GP responses obtained using the method of Eberhart and Russell (1966) and those classified as MEDG by the multiple centroid method showed an association. Hence, further studies with a higher number of genotypes are needed to contemplate all response classes.

\section{Conclusions}

1. The correspondence analysis technique was suitable for determining response associations and discrimination potential of adaptability and stability methods.

2. U (unfavorable) and UU (unfavorable unpredictable) responses obtained using the methods of Lin and Binns (1988) and Eberhart and
Russell (1966), respectively, showed conflicting associations with other responses obtained using these methods.

3. Among all the evaluated methods, only the methods of Eberhart and Russell (1966) with Cruz, Torres and Vencovsky (1989) and Eberhart and Russell (1966) with Nascimento et al. (2009b), showed an association between the responses.

\section{References}

CARMO, M. R. B. do; ASSIS, M. A. de. Caracterização florística e estrutural das florestas naturalmente fragmentadas no Parque Estadual do Guartelá, município de Tibagi, estado do Paraná. Acta Botanica Brasilica, São Paulo, v. 26, n. 1, p. 133-145, 2012.

CRUZ, C. D.; REGAZZI, A. J.; CARNEIRO, P. C. S. Modelos biométricos aplicados ao melhoramento genético. 3. ed. Viçosa: UFV, 2004. v. 1, 480 p.

CRUZ, C. D.; TORRES, R. A.; VENCOVSKY, R. An alternative approach to the stability analysis proposed by Silva and Barreto. Revista Brasileira de Genética, Ribeirão Preto, v. 12, n. 3, p. 567-80, 1989.

EBERHART, S.A.; RUSSELL, W. A. Stability parameters for comparing varieties. Crop Science, Madison, v. 6, n. 1, p. 36-40, 1966.

GAUCH JUNIOR, H. G. Statistical analysis of yield trials by AMMI and GGE. Crop Science, Madison, v. 46, n. 4, p. 488-1500, 2006.

JOHNSON, R. A.; WICHERN, D. W. Applied multivariate statistical analysis. $4^{\text {th }}$ ed. New Jersey: Prentice Hall, 1999. 815 p.

LIN, C. S.; BINNS, M. R. A superiority measure of cultivar performance for cultivar $\times$ location data. Canadian Journal of Plant Science, Ottawa, v. 68, n. 1, p. 193-198, 1988.

LOPES JUNIOR, J. C.; RAMOS, C. E. C. de O.; SANTOS, G. T. dos; GRANDE, P. A.; AMASCENO, J. C.; MASSUDAS, E. M. Análise das práticas de produtores em sistemas de produção leiteiros e seus resultados na produção e qualidade do leite. Semina: Ciências Agrárias, Londrina, v. 33, n. 3, p. 1199-1208, 2012.

MAHAMMADI, R.; AMRI, A. Comparison of parametric and non-parametric methods for selecting stable and adapted durum wheat genotypes in variable environments. Euphytica, Wageningen, v. 159, n. 3, p. 419-432, 2008. 
MINGOTI, S. A. Análise de dados através de métodos de estatística multivariada - uma abordagem prática. Belo Horizonte: Editora UFMG, 2005. 295 p.

NASCIMENTO, M.; CRUZ, C. D.; CAMPANA, A. C. M.; TOMAZ, R. S.; SALGADO, C. C.; FERREIRA, R. de P. Alteração no método centroide de avaliação da adaptabilidade genotípica, Pesquisa Agropecuária Brasileira, Brasília, v. 44, n. 3, p. 263-269, 2009 b.

NASCIMENTO, M.; FERREIRA, A.; CAMPANA, A. C. M.; SAlGADO, C. C.; CRUZ, C. D. Multiple centroid methodology to analyze genotype adaptability. Crop Breeding and Applied Biotechnology, Londrina, v. 9, n. 1, p. 8-16, 2009a.

NASCIMENTO, M.; FERREIRA, A.; FERRÃO, R. G.; CAMPANA, A. C. M.; BHERING, L. L.; CRUZ, C. D.; FERRÃO, M. A. G.; FONSECA, A. F. A. da Adaptabilidade e estabilidade via regressão não paramétrica em genótipos de café. Pesquisa Agropecuária Brasileira, Brasília, v. 45, n. 1, p. 45-48, 2010.

NASCIMENTO, M.; SILVA, F. F. e; SÁFADI, T.; NASCIMENTO, A. C. C.; FERREIRA, R. de P.; CRUZ, C. D. Abordagem bayesiana para avaliação da adaptabilidade e estabilidade de genotypes de alfafa. Pesquisa Agropecuária Brasileira, Brasília, v. 46, n. 1, p. 26-32, 2011.

ROCHA, R. B.; ABAD, J. I. M.; ARAUJO, E. F.; CRUZ, C. D. Avaliação do método centróide para estudo de adaptabilidade ao ambiente de clones de Eucalyptus grandis. Ciência Florestal, Santa Maria, v. 15, n. 3, p. 255-266, 2005.

ROSSE, L. N.; VENCOVSKY, R.; FERREIRA, D. F. Comparação de métodos de regressão para avaliar a estabilidade fenotípica em cana-de-açúcar. Pesquisa Agropecuária Brasileira, Brasília, v. 37, n. 1, p. 25-32, 2002.

SABAGHNIA, N.; DEHGHANI, H.; SABAGHPOUR, S. H. Nonparametric methods for interpreting genotype 3 environment interaction of lentil genotypes. Crop Science, Madison, v. 46, n. 3, p. 1100-1106, 2006.

SILVA, W. C. J. e; DUARTE, J. B. Métodos estatísticos para estudo de adaptabilidade e estabilidade fenotípica em soja. Pesquisa Agropecuária Brasileira, Brasília, v. 41, n. 1, p. 23-30, 2006. 
